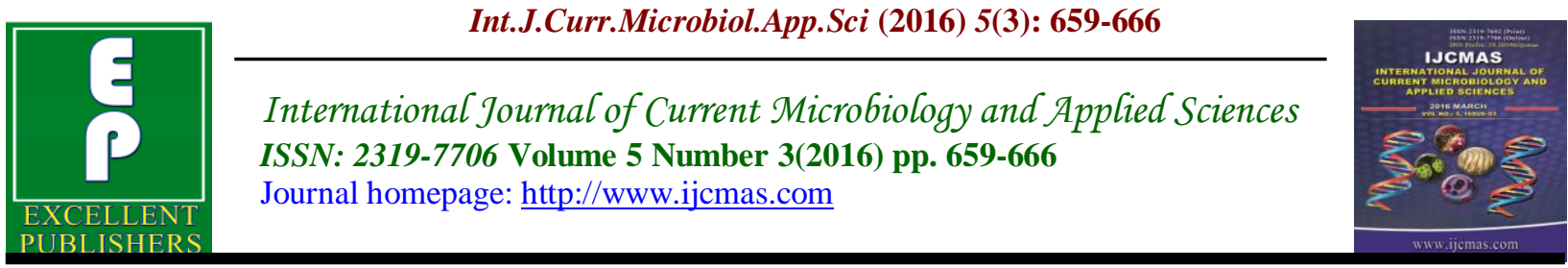

Original Research Article

http://dx.doi.org/10.20546/ijcmas.2016.503.077

\title{
Influence of Arbuscular Mycorrhizae Inoculation on Growth and Development of Hibiscus rosa sinensis
}

\author{
Soniya Kasliwal* and K. M. Srinivasamurthy \\ Department of Microbiology and Biotechnology, JB Campus, \\ Bangalore University, Bangalore, India \\ *Corresponding author
}

\begin{abstract}
A B S T R A C T
Keywords

Arbuscular

Mycorrhiza,

Glomus mosseae,

Hibiscus rosa

sinensis, Physical

growth parameters

Macro and

micronutrients.

Article Info

Accepted:

20 February 2016

Available Online:

10, March 2016

Hibiscus rosa sinensis is an evergreen herbaceous plant known to possess medicinal properties like oral contraceptive, laxative, aphrodisiac, menorrhagic etc. In the current study influence of Arbuscular Mycorrhiza (Glomus mosseae) inoculation on Hibicus rosa sinensis was studied for 60 days in open potted experiments. Physical growth parameters viz shoot length, root length, fresh weight, and dry weight of plants were studied. Macro and micronutrients $(\mathrm{N}, \mathrm{P}, \mathrm{K}$, $\mathrm{Ca}, \mathrm{Mg}, \mathrm{Zn}, \mathrm{Fe}, \mathrm{Cu}, \mathrm{Mn}, \mathrm{B}$ and $\mathrm{Mo}$ ) were analyzed in roots and leaves of plant. Root colonization study was done and percentage root infection was calculated. Glomus mosseae inoculated plants revealed more growth with nearby $60 \%$ increase in shoot length and 33\% increase in number of leaves. The concentration of macronutrients $\mathrm{N}, \mathrm{P}, \mathrm{K}$ and $\mathrm{Zn}$ was also found more in GM plants. GM treatment was found to be successful for Hibiscus rosa sinensis plant and hence can be used as an ecofriendly measure for mass multiplication of Hibiscus rosa sinensis. However effect of other AM species in combination with phosphate solubilizers on Hibiscus rosa sinensis can also be studied in future.
\end{abstract}

\section{Introduction}

The term Mycorrhiza was coined by A.B. Frank in 1885 (Frank, 1885). Mycorrhiza is the mutualistic symbiotic association between soil borne fungi and roots of higher plants in which both are benefitted (Sieverding et al., 1991; Sayeeda et al., 2013). Arbuscular mycorrhiza is the mutualistic symbiotic association between most vascular land plant species and fungi of phylum Glomeromycota (Smith and Read, 2008; Anju et al., 2011).
AM fungus penetrates the cortical cells of roots of higher plants and forms vesicles and arbuscules. Arbuscules are structures produced within the host plant cells by the AM fungi. These structures are responsible for the transfer of absorbed nutrients from the fungus to the plant (Sandeepa, 2013). AM fungi improve plant growth by capturing relatively immobile nutrients like phosphorus (Souchie et al., 2006),other macroelements (Hodge et al., 2001) and 
some microelements (Faber et al., 1990; Anju et al., 2011).

Glomus mosseae is a representative species of endogonaceae (Phycomycetes) able to form AM.The microorganism synthesizes two gibberellins like substances (Jose M Barea,1982) Glomus mosseae can transport a considerable amount of phosphate and nitrogen to the plant from soil zones several centimeters from root (Eckhard, 1992). Amongst single inoculation treatment, $G$. mosseae increased maximum growth parameters, over the control in Capsicum annum (Anju et al., 2011). Metal accumulation changes in Cannabis sativa (L) with Glomus mosseae interaction is also reported (Sandra et al., 2005)

Hibiscus rosa sinensis is an evergreen herbaceous plant, which belongs to family Malvaceae and is commonly known as Jasvand.It is an evergreen woody glabrous showy shrub 5- 8 feet in height (Kirtikar et al., 1987).The plant is native to China and is also found in India and Philippines. It is widely cultivated in the tropics as an ornamental plant and has several forms with varying colours of flowers (Bhaskar A, 2011).Different parts of plants viz roots, stems, leaves and flowers are medicinally important and have been known to possess medicinal properties. Flowers are used in all kinds of inflammation, internally they are prescribed in form of decoction of bronchial catarrah,as a becenic acid and subdorific roots are mucilaginous and demulcent, valuable in cough (Caius J F,1992 ; Satyavati et al., 1997).Root powder of plant is useful in mennorhagia and root juice in gonorrhea whereas leaves are used for fatigue and skin diseases. (Wealth of India, 1959). Literature supports antifertility activity in the plant (Batta S K et al., 1970). Hibiscus rosa sinensis plant has shown mycorrhizal association (Muthukumar et al., 2006 ; Radhika,2010) Jonathan N have studied the effect of Glomus intradices on Hibiscus rosa sinensis (Jonathan ,1998). Macro and micronutrient analysis in leaves of Hibiscus rosa sinensis for drought conditions has also been studied (Egilla et al.2001)

The present study was conducted with the objective of studying the influence of Glomus mosseae inoculation on Hibiscus rosa sinensis on physical growth parameters and macro and micronutrient analysis viz $\mathrm{N}$, $\mathrm{P}, \mathrm{K}, \mathrm{Ca}, \mathrm{Mg}, \mathrm{Zn}, \mathrm{Fe}, \mathrm{Cu}, \mathrm{Mn}, \mathrm{B}$ and $\mathrm{Mo}$ in leaves and roots of the plant.

\section{Materials and Methods}

\section{Experimental Design}

Experiments were carried out as open pot experiments in plastic pots for 60 days through random block design method at the Medicinal plant garden of Department of Microbiology and Biotechnology, Bangalore University, Jnana Bharthi Campus , Bangalore. The temperature varied from $32^{\circ}$ $\mathrm{C}-17^{\circ} \mathrm{C}$ during the experiment.

\section{Soil Characteristics}

The soil and sand sample were collected from nurseries near to Bangalore University.Soil is red clay soil with $\mathrm{pH}$ value 8.1(Jackson, 1973). Soil and sand samples were mixed in 1:1 ratio and farmyard manure was added and the mixture was autoclaved at $15 \mathrm{lbs}$ for 20 mins for two consecutive days. Plastic pots were taken and sterilized. $3 \mathrm{~kg}$ of soil per pot was added.

\section{Plant Sample and Glomus mosseae Treatments}

One month old plant seedlings of Hibiscus rosa sinensis were collected from 
Sanjeevani vatika, Department of Horticulture, University of Agriculture Sciences, Gandhi krishi vignan kendra, Bangalore. Glomus mosseae spores were procured from Department of Microbiology, University of Agriculture Sciences, Gandhi krishi vignan kendra, Bangalore. Glomus mosseae inoculums were prepared as per protocol given by Menge and Timmer (1982). Pot based cultures were done and root based inoculums were used for further treatments. Plant seedlings were inoculated for 60 days with Glomus mosseae culture. The plants were watered on alternate days.

\section{Plant Harvesting and Measurement of Physical Growth Parameters}

Plants were harvested after 60 days of inoculation and physical growth parameters of plants viz root length, shoot length, fresh weight, dry weight and numbers of leaves were studied. Shoot length $(\mathrm{cm})$ and number of leaves were first measured in the standing plant. After harvesting fresh weight and root length of plant were noted . The sample was then oven dried at $80^{\circ} \mathrm{C}$ for $72 \mathrm{hrs}$ till a constant weight is achieved and later dry weight of the plants were recorded.

\section{Macro and Micro Nutrient Analysis}

Fresh leaves and root samples were oven dried by maintaining the samples in oven at $80{ }^{\circ} \mathrm{C}$ for $72 \mathrm{hrs}$ till a constant weight is achieved.The dried samples were then crushed in powder form using mortar and pestle and later in mixer grinder to achieve powder form. Macro and micro nutrient analysis for leaf and roots samples of control and Glomus mosseae inoculated plants were done by emission spectrometry by using ICP-OES technique (Matthew $\mathrm{S}$ et al,2011; Momen A et al 2007) with the help of ICP-OES 7000 DV (Make -Perkin Elmer) The different Macro and
Micronutrients analyzed were Nitrogen $(\mathrm{N})$ $\%$, Phosphorus (P O)\%, Potassium $\left(\mathrm{K}_{2} \mathrm{O}\right) \%$, Calcium (Ca) \%,Magnesium (Mg) \%, Zinc (Zn) ppm, Iron $(\mathrm{Fe}) \mathrm{ppm}$, Copper $(\mathrm{Cu}) \mathrm{ppm}$, Manganese (Mn) ppm Boron (B) ppm and Molybdenum (Mo).

\section{Root Colonization Study}

Root Colonization was studied by 'Rapid clearing and Staining technique' (Philips and Hayman, 1970). The technique involves microscopic observation of AM fungi fungal colonization after clearing roots in $\mathrm{KOH}$ $(10 \%)$ and staining with trypan blue $(0.5 \%)$, Percentage mycorrhizal root colonization (\%) was measured by gridline intersect method (Giovannetti and Mosesse, 1980). A total of 50 root fragments were studied.

Percentage root colonization $=$

Total no of root segments infected $\quad$ x 100

Total no of root segments studied

\section{Results and Discussion}

The effect of inoculation of Glomus mosseae on growth and development of Hibiscus rosa- sinensis was studied (Table: 1).Change in shoot length was significant with $60 \%$ more in GM inoculated $(42.67 \pm 6.17)$ than uninoculated control plants $(29.29 \pm 1.819)$ (Table 1). The root length in GM inoculated plant was found to be $61.9 \%$ more in GM inoculated $(30.87 \pm 5.906)$ and control (19.06 \pm 5.178$)$ (Fig : 1). The number of leaves was almost double in GM leaves $(19.5 \pm 17)$ than in control leaves $(14 \pm 4)$ (Table :1).Similarly fresh weight and dry weight was also found to be significantly more in GM inoculated with fresh weight (14.24 \pm 6.139) and dry weight (3.24 \pm $0.46) .67 \%$ root colonization was found in GM roots. 
Table.1 Studies on Physical Parameters of Growth in Hibiscus rosa sinensis after 60 Days*

\begin{tabular}{|c|c|c|}
\hline 60 Days & $\begin{array}{c}\text { Control } \\
\text { (Uninoculated) }\end{array}$ & GM inoculated \\
\hline Shoot length $(\mathrm{cm})$ & $29.29 \pm 1.819$ & $42.67 \pm 6.17$ \\
\hline Root length $(\mathrm{cm})$ & $19.06 \pm 5.1786$ & $30.87 \pm 5.906$ \\
\hline Number of leaves & $14 \pm 4$ & $19.5 \pm 17$ \\
\hline Fresh weight $(\mathrm{g})$ & $11.038 \pm 6.29$ & $14.24 \pm 6.139$ \\
\hline Dry weight $(\mathrm{g})$ & $2.85 \pm 0.36$ & $3.24 \pm 0.46$ \\
\hline
\end{tabular}

*Values are taken as mean of triplicates

Table.2 Chemical Analysis in Roots and Leaves of Control Uninoculated and GM Inoculated Plant of Hibiscus rosa- sinensis for 60 days

\begin{tabular}{|c|c|c|c|c|}
\hline Chemical & Control leaves & $\begin{array}{c}\text { GM inoculated } \\
\text { leaves }\end{array}$ & Control root & $\begin{array}{c}\text { GM inoculated } \\
\text { root }\end{array}$ \\
\hline Nitrogen (\%) & 1.47 & 1.87 & 1.58 & 1.72 \\
\hline Phosphorus (\%) & 1.12 & 1.45 & 0.67 & 0.75 \\
\hline Potassium (\%) & 2.4 & 2.5 & 2.65 & 2.82 \\
\hline Calcium (\%) & 2.53 & 2.73 & 0.57 & 0.86 \\
\hline Magnesium (\%) & 0.89 & 0.93 & 0.57 & 0.53 \\
\hline Zinc (ppm) & 13.12 & 17.54 & 53.19 & 110.1 \\
\hline Iron (ppm) & 639.4 & 583.2 & 6740 & 9631 \\
\hline Copper (ppm) & 50.64 & 19.18 & 75.05 & 468.9 \\
\hline Manganese (ppm) & 26.49 & 31.94 & 55.09 & 98.71 \\
\hline Boron (ppm) & 80.59 & 63.74 & 47.48 & 49.37 \\
\hline Molybdenum(ppm) & 12.61 & 9.42 & 169.4 & 249.5 \\
\hline
\end{tabular}

Fig.1 Shoot Length and Root Length for 60 Days GM Inoculated and Control Uninoculated Plants of Hibiscus rosa sinensis

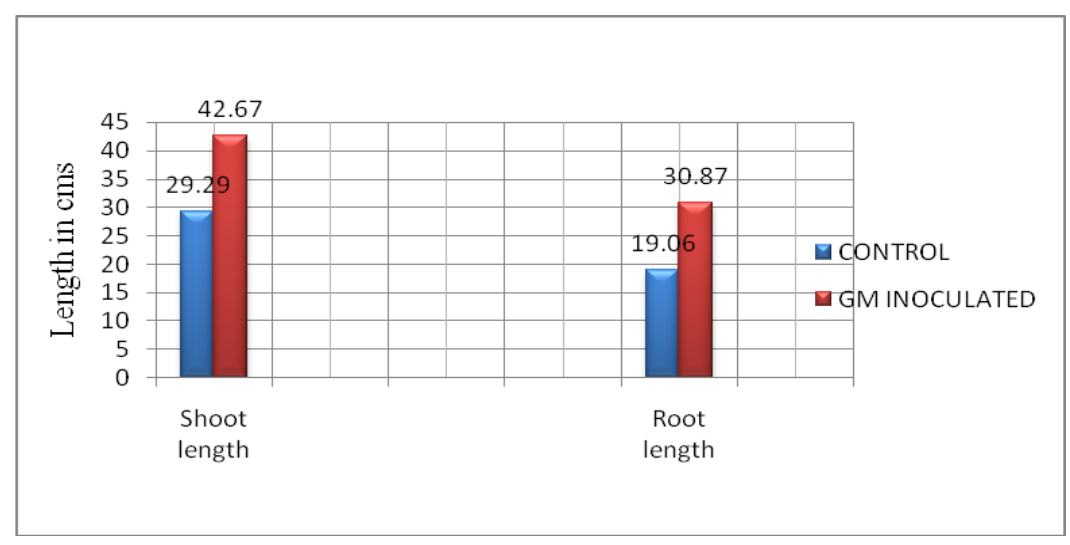

A trend similar to plant growth was observed for nitrogen, phosphorus and potassium when calculated for leaves and roots (Table: 2). The total $\mathrm{N}$ percentage in GM treated leaves $(1.87 \%)$ was significantly higher than in control leaves 
$(1.47 \%)$ and the trend was similar for roots with $\mathrm{N}$ being $1.72 \%$ in GM roots and control roots $1.52 \%$. The trend continued for phosphorus and potassium and $\mathrm{P}$ percentage in root revealed difference with $0.75 \% \mathrm{P}$ in $\mathrm{GM}$ roots and $0.67 \%$ in control roots but leaves show a difference comparable as $1.45 \%$ in GM leaves and $1.12 \%$ in control leaves. Potassium was noticed to be $2.82 \%$ in GM treated roots with $2.65 \%$ in control roots and $2.5 \%$ in GM leaves and $2.4 \%$ in control leaves. Similar trend was observed for calcium with the nutrient concentration being more in $\mathrm{AM}$ inoculated leaves and roots with $2.73 \% \mathrm{Ca}$ in $\mathrm{GM}$ leaves and $0.86 \% \mathrm{Ca}$ in $\mathrm{GM}$ roots (Table : 2). Some elements showed a controversial result like Magnesium having more percentage $0.93 \%$ $\mathrm{Mg}$ in GM leaves and $0.89 \% \mathrm{Mg}$ in control leaves, the roots showed a difference with $0.53 \% \mathrm{Mg}$ in GM roots which is less compared to $0.57 \% \mathrm{Mg}$ in control roots.Zinc behaved in same manner with concentration in inoculated GM roots being $110.1 \mathrm{ppm}$ and control roots $53.19 \mathrm{ppm}$. Fe, $\mathrm{Cu}$ and Mo had very high concentration in roots whereas the concentration was significantly less in leaves. The $\mathrm{Fe}$ concentration was found to be $9631 \mathrm{ppm}$ in $\mathrm{GM}$ roots and and $6740 \mathrm{ppm}$ in control roots whereas $583.2 \mathrm{ppm}$ Fe was found in GM leaves which was less than control leaves with $639.4 \mathrm{ppm}$ Fe concentration. The concentration of $\mathrm{Cu}$ was almost four times in GM roots with 468.9 ppm $\mathrm{Cu}$ concentration and control having $75.05 \mathrm{ppm}$ concentration. The concentration of boron was found to be different with more being in leaves than in roots. Boron concentration was $49.37 \mathrm{ppm}$ of $\mathrm{B}$ in GM roots whereas it was 47.48 of ppm B in control root. Control leaves had higher concentration of $B$ with 80.59 ppm with the inoculated leaves 63.74 ppm of B.The concentration of molybdenum was found to be $249.5 \mathrm{ppm}$ Mo in inoculated root and 169.4 ppm of Mo in control root whereas it was found to be comparatively very less in leaves with $9.42 \mathrm{ppm}$ in GM leaves and $12.61 \mathrm{ppm}$ in control leaves.

In general the GM inoculated plants were found to show better results as compared to control in physical growth parameters and macro and micronutrients analysis. The enhanced growth is due to the ability of AM fungi to increase nutrient uptake of plants by developing an association with roots (Schreiner et al., 1997) and sometimes also by promoting the growth of other rhizospheric micro-organisms and thus enhancing plant growth (Johnson et al., 2004). The other reason can be that,once host roots are colonized by AM fungi,it changes the root exudates released and produces phosphatase enzyme in rhizosphere. These phosphatases produced by extraradical hyphae of AM fungi could hydrolyze extracellular phosphate ester bonds and ultimately made Phosphorus available to plants (Joner et al., 2000).Earlier studies have also shown that Glomus mosseae increases plant height,stem girth,biomass, $\mathrm{P}$ content, $\mathrm{Zn}$ concentration, biovolume index and quality index than uninoculated control plants (Sumana and Bagyaraj,1999; Sundarbabuk,2001).The nutrient uptake results resembled to earlier work performed.It is feasible that external hyphae may provide a significant delivery system for $\mathrm{N}, \mathrm{P}, \mathrm{Cu}$ and $\mathrm{Zn}$ in addition to $\mathrm{P}$ in many soils (Marschner et al., 1994).Increase in uptake of copper and manganese in AM inoculated plant has also been shown (Krishna,1983; M.Farzaneh, 2011).

Based on the response on different physical growth parameters like shoot length, root length fresh weight, dry weight and number of leaves and macro and micro nutrient analysis like N,P,K and Zn content it can be concluded that AM specie Glomus mosseae can be used as best consortia for Hibiscus 
rosa sinensis. This technology being simple and eco friendly can also be used by nurserymen for horticulture purposes or for its medicinal value. Although further studies can also be performed with trying different combinations of Phosphate solubilizers or different arbuscular mycorrhizae species.

\section{Acknowledgement}

The author is grateful to Department of Microbiology and Biotechnology, Bangalore University, Bangalore for providing research facilities.

\section{References}

Anju Tanwar.,Ashok Aggarwal.,Alpa Yadav and Nisha Kadian.2011. Enhanced growth and yield of Capsicum annum L.with two endomycorrhizal fungi and other bioinoculants. Journal of Indian Botanical Science.90 (3 \& 4): 351-359.

Batta, S. K., Santhakumari,G. 1970.The anti-infertility effect of Ocimum sanctum and Hibiscus rosa sinensis. Indian J Med Res. 59: 777-781.

Bhaskar,A. 2011. Evaluation of hypolipidemic activity of Hibiscus rosa sinensis L. Journal of Pharmacy Research.4(10): 3293-3294.

Caius,J.F.1992.The medicinal and poisonous plant of India.Scientific Publishers, Pp 457-458.

Eckhard George., Karl Uue., Haussler., Dorris Vetterlein. and Eva, Gorgus. 1992. Water and Nutrient translocation by Hyphae of Glomus mosseae. Canadian Journal of Botany. 70: 2130 -2137.

Egilla, J. N., Davies, F.T. and Drew,M. C.2001.Effect of potassium on drought resistance of Hibiscus rosa sinensis $\mathrm{Cv}$, Leprechaun : Plant growth, leaf macro and micronutrients, content and root longevity.Plant and Soil.229;213 224.

Faber, B. A., Zasoki,R.J.,Burau,R.G. and Uriu, K.1990. Zinc uptake by corns as affected by Vesicular Arbuscular mycorrhiza. Plant and soil.129:121130.

Frank, A.B. 1885. Über die auf Wurzelsymbiose beruhendc Ernahrung gewisser Baume duren unterirdischePilzc. Ber.dtsch. Bot. Ges. 3: 128-145.

Gerdemann, J.W. and T.H. Nicolson.1963. Spores of mycorrhizal endogone species extracted by wet sieving and decanting, Transactions of the British Mycological Society. 46:235244.

Gilani, A. H, Bashir, S., Janbaz, K. H., Shah A.J. 2005. Presence of cholinergic and calcium channel blocking activities explains the traditional use of Hibiscus rosa sinensis in constipation and diarrhea. Journal of Ethnopharmacology. 102:289-294.

Giovanneti, M. and Mosse, B. (1980). An evolution of technique for measuring vesicular arbuscular Mycorrhizal infection in roots. New Phytologist.84: 489-500.

Harley, J.L and Smith, S.E. (1983). Mycorrhizal Symbiosis, Academic Press, London

Kirtikar, K.R., Mayor and Basu, B.D.1987. Indian medicinal plants. 1:335-336.

Hodge,A.,Campbell,C.D. and Fitter,A.H. 2001.An Arbuscular mycorrhizal fungus accelerates decomposition and acquires nitrogen directly from organic material.Nature.413 :297299.

Jackson,M.L.1973.Soil Chemical Analysis.Prentice hall of India pvt Ltd, New Delhi.

Johnson,J.F., Paul, L.R. and Finley,R.D. 
2004. Microbial interaction in the mycorrhizaosphere and their significance for sustainable agriculture. FEMS Microbiol Ecol.48: 1-13.

Joner,E.J.,Briones,R.and Leyval.2000.Metal binding capacity of arbuscular mycorrhizal fungi.Plant soil. 226 : 227-234.

Jose,M. Barea and Concepcion, Azcon, Aguilar. 1982. Production of plant growth regulating Substances by the Vesicular Arbuscular Mycorrhizal fungal Glomus mosseae. Applied And Environmental Microbiology,43 (4) :810-813.

K.P.Radhika and B.F.Rodriguez.2010. Arbuscular mycorrhizal fungal diversity in some commonly occurring Medicinal plants of Western ghats, Goa region.Journal of Forestry Research. 21 : 45-52.

M.Sandeepa,G. 2013. Effect of Glomus mosseae on growth of selected plant species. International Journal of Bio - pharma Research. 2 (6): 144-145

Matthew, S. Wheal., Teresa, O. Fowles. and Lyndon, T. Palmer. 2011. A cost-effective acid digestion method using closed polypropylene tubes for inductively coupled plasma optical emission spectrometry (ICPOES) analysis of plant essential elements. Analytical Methods.3, 2854-2863.

Menge,J.A., Timmer, L.W..1982. Procedures for inoculation of plants with Vesicular-arbuscular mycorrhizae in the laboratory, greenhouse, and field. In: Schenck N.C. (eds): Methods and Principles of Mycorrhizal Research. American Phytopathological Society, St. Paul Pp 59-68.

Momen, A.A., Zachariadis, G.A., Anthemidis, A.N., Stratis, J.A.2007.
Use of fractional factorial design for optimization of digestion procedures followed by multi-element determination of essential and nonessential elements in nuts using ICPOES technique. Talanta. 71 (1) 443 451.

Philips, J. M. and Hayman,D. S..1970. Improved procedures for clearing roots and staining parasitic and VAM fungi for rapid assessment of infection. Trans. Brit. Mcol. Soc.55: 158- 161.

Sandra Citterio.,Nadia Prato.,Pietro Fumagalli.,Roberta Aina.,Nadia Massa.,Angela Santagostina.,Sergio Sgorbati. and Graziella Berta.2005.The arbuscular mycorrhizal fungus Glomus mosseae induces growth and metal accumulation changes in Cannabis sativa. Chemosphere.59 (1):21-29.

Sayeeda, K. B., Aditya K., Tanuja, R. and Navroop, K. 2013. Influence of AM fungi (Glomus mosseae, Acaulospora laevis and Gigaspora sp.) alone and in Combination with Trichoderma viride on growth responses and physiological parameters of Dianthus caryophyllus Linn. 4 (2) :13- 20

Satyavati, G.V., Gupta, A.K., Tondon, N. 1987. Medicinal plants of India, New Delhi 7. IndianCouncil of Medical Research, Vol.2.

Schreiner, R.P., Mihara, K.L., Mc.Daniel, H and Bethlenfavoy, G.J.1997. Mycorrhizal fungi improves plant and soil functions and interactions. Plant soil.188: 199 -207.

Sieverding, E. 1991. Vesicular -arbuscular mycorrhiza management in tropical agrosystems. Technical Cooperation, Federal Republic of Germany Eschborn.

Smith, S and Read, D.2008.Mycorrhizal 
Symbiosis. 3 edn. New York Academic Press.

Souchie, E. L., Azcon R., Barea, J.M., Saggin -Junior.O.J. and Riberio da Silva E.M. 2006.Phosphate solubilizing and arbuscular mycorrhizal fungi.Pesq Agropec Bras.41(9): $1405-1411$.

The Wealth of India. Raw materials.1959. 5. New Delhi. CSIR: 91.
T. Muthukumar., M.Senthil, Kumar., M. Rajanangam. and $\mathrm{K}$. Udaiyan.2006.Arbuscular Mycorrhizal morphology and dark septate fungal associations in medicinal and aromatic plants of Western ghats, Southern India, mycorrhizae. 17 (1): 11-24

\section{How to cite this article:}

Soniya Kasliwal and Srinivasamurthy, K. M. 2016. Influence of Arbuscular Mycorrhizae Inoculation on Growth and Development of Hibiscus rosa sinensis. Int.J.Curr.Microbiol.App.Sci. 5(3): 659-666. doi: http://dx.doi.org/10.20546/ijcmas.2016.503.077 